\title{
Some Physicochemical Charateristics of Badagry Creek, Nigeria
}

\author{
S. L. Akintola*, M. A. Anetekhai and E. O. Lawson \\ Fisheries Department, Lagos State University, Ojo P.O Box 001, LASU, Lagos, Nigeria \\ *Corresponding author; E-mails: shehu.akintola@lasunigeria.org;drsilfa@yahoo.com
}

\begin{abstract}
Badagry Creek runs through Nigeria and Republic of Benin with access to the Atlantic Ocean. Physicochemical parameters of the creek were studied from 2003 to 2004 to generate baseline data in view of its increasingly importance in economic life and developmental issues. Two important sites, with highest human activities, Akarakumo and Topo, were chosen for monthly analyses of water samples following methods and procedures of APHA. Colour, surface temperature, $p \mathrm{H}$, salinity, turbidity, phenol, dissolved oxygen, biological oxygen demand, conductivity, total suspended solids, total dissolved solids, total hardness (calcium and magnesium), nitrates, phosphates, sulphates, chlorides, free carbon dioxide, acidity, oil and greese were analysed. There were significant difference in monthly variations $(P<0.05)$ of all the parameters except for ammonia $(P>0.05)$. The mean concentration of the parameters showed significant variation with mean values of $27.51 \pm 1.17^{\circ} \mathrm{C}$ for temperature, biological oxygen demand $18.38 \pm 8.14 \mathrm{mg} / 1$, free carbon dioxide, $4.00 \pm 2.07 \mathrm{mg} / \mathrm{l}$ and ammonia $0.18 \pm 0.15 \mathrm{mg} / 1$. Values were within those reported for most estuaries globally. It was revealed that variations in the water quality of the creek are largely influenced by season and intrusion from the ocean at different tide levels.
\end{abstract}

\section{Introduction}

Tidal influence on estuaries has a unique combination of physical and chemical characteristics which govern lives of organisms therein (Peter \& Michael, 2005). Estuaries are known to provide important support in the completion of the life cycles of many Euryhaline organisms.

The forms and state of well being of aquatic animals are influenced by the state of water quality of the aquatic biomes in which they are found. In recent years there has been an increase in land-use in the catchment areas of tropical rivers, e.g. for farming, roads, logging, mining, etc., resulting in the introduction of pollutants from industries, agro-chemicals and mine effluents into some of the rivers (Ameka et al., 2007). Water quality degradation by various sources has become an important issue around the world. Usage of more land for agricultural purposes with application of chemicals and erosion has become problems threatening natural water source (Zalidis et al., 2002).

Industrial waste discharge into Badagry Creek and the water conditions is not known presently. Nevertheless, the creek supports the artisanal fisheries, water ways and cultural values in the area. Physicochemical properties of water quality usually reveal the status, productivity and sustainability of such water body. The changes in some physicochemical characteristics like temperature, transparency, dissolved oxygen, chemical oxygen demand, nitrate and phosphate provide valuable information on the quality of the water, and their impacts on the functions and biodiversity of a reservoir (Mustapha, 2008).

The study is aimed at assessing the water quality of Badagry Creek, which runs through Benin Republic and Nigeria, using 
some physicochemical properties. This will generate baseline data for monitoring and tracking changes in the water quality, bearing in mind the creek natural dynamics over time, and possible impact of human activities such as dredging, and fishing in the creek and its bank.

\section{Materials and methods}

Studyarea

Badagry Creek is located on latitude $2^{\circ} 42^{\prime}$ and $3^{\circ} 2^{\prime} \mathrm{E}$ and between longitude $6^{\circ} 23$ and 6 $28^{\prime} \mathrm{N}$, and forms part of the continuous lagoon that stretches from Port Novo to Lagos (Fig. 1). It is estimated to be more than $51 \mathrm{~km}$ from Lagos. It is bounded in the north by the Egbado plateau, and in the west by River Yewa via Ologe lagoon, and in the south by the Atlantic Ocean, and in the east by the expanse of the mangrove swamp. The climate is dominated by heavy rainy season which last from April to October. The rain is marked by two peaks in May to July, and September to October. Rainfall is usually heavier during the first period (52\%), creating serious flash floods which are aggravated by the characteristics poor surface drainage conditions of the coastal lowlands.

The soil in Badagry is light grey sandy type with vegetation over the low lying plains and marshes near the lagoons and creeks. The vegetation is made up of woody plants, shrubs, and oil palm trees in the sandy areas, while the marshy areas are covered by mangrove. The mean monthly temperature fluctuates around $30{ }^{\circ} \mathrm{C}$. The highest temperatures occur around November to December, and February to March, when there is a short dry season. The relative humidity is high throughout the year and may not be less than about $70-80 \%$ around Lagos and other lagoons, and seaside locations. The consequence of the humid conditions is that it promotes the rapid growth of dense vegetation, and a large population of zooplanktons in the mixed waters of the lagoons and creeks (Abegunde, 2002).

\section{Water quality}

Two sampling stations, Topo (A) and Akarakumo (B), about $5 \mathrm{~km}$ apart, were selected. Monthly water samples from these stations were taken twice between 7-10 a.m. in 1.5-litre plastic container, which was rinsed three times with the creek water before the plastic container was filled up, and preserved in an ice chest. Thereafter, the samples were taken to the laboratory for analyses. Physicochemical parameters studied following APHA et al. (1985) are colour, temperature, $p \mathrm{H}$, salinity, turbidity, dissolved oxygen, biochemical oxygen demand, settleable solids, alkalinity, total hardness (calcium and magnesium), conductivity, acidity, free carbon dioxide, chloride, sulphate, nitrate, phosphate, ammonia and total dissoved solids. A blank sample was prepared for confirmation of the results while surface water temperature was measured in situ.

\section{Statistical analyses}

Routine estimation was carried out using SPSS (2001) to test for differences in the values of parameters monthly and sampling sites. ANOVA and dependent t-test were employed to assess monthly, seasonal and annual variations in the physical and chemical parameter of the creek.

\section{Results}

The mean monthly colour variation in the sampling stations is presented in Fig. 2. The 
highest mean value of $34.00 \pm 10.55$ (TCU) was recorded in July and the lowest value in December with a mean value of $16.00 \pm 6.38$ (TCU) in both stations in 2004. Rainy season values were significantly higher $(P<0.05)$ in the dry season. Surface water temperatures in Fig. 2 was not significantly different $(P>$ $0.05)$ in the stations and months (mean $=$ $27.51 \pm 1.17{ }^{\circ} \mathrm{C}$; range $\left.=26.00-31.00{ }^{\circ} \mathrm{C}\right)$, however, a significant difference $(P<0.05)$ was obtained in years.

The highest $p \mathrm{H}$ mean value of $8.97 \pm 1.37$ was recorded in June in 2004 for both stations while the lowest values in the stations were recorded in November as seen in Fig. 2. Values of the $p \mathrm{H}$ were significantly different in months $(P<0.05)$. Significantly higher values of salinity $(P<0.05)$ was obtained in the wet season compared to the dry season, with highest values of $5.48 \%$ in June 2003 and lowest value of $0.02 \%$ in January-March in both years and stations (Fig. 2). The highest monthly mean turbidity value of $28.00 \pm 4.55$ NTU was recorded in November 2003 against the lowest value of $9.25 \pm 0.50 \mathrm{NTU}$ in December 2004 (Fig. 2). Turbidity varied significantly $(P<0.05)$ in months.

Mean monthly values for dissolved oxygen is presented in Fig. 3 with no significant difference $(P>0.05)$ recorded in the years and sampling stations. Dissolved oxygen mean value of $4.55 \pm 0.49 \mathrm{mg} / \mathrm{l}$ prevailed in the period of study and varied significantly $(P<0.05)$ monthly, with highest concentration in August (mean $=5.13 \pm 0.32$ $\mathrm{mg} / \mathrm{l}$ ) and lowest value in April (mean $=3.69$ $\pm 0.22 \mathrm{mg} / \mathrm{l})$. The recorded concentration of ammonia in Badagry Creek was relatively not dispersed $($ mean $=0.18 \pm 0.15 \mathrm{mg} / \mathrm{l}$, range $=$ $0.05-0.80 \mathrm{mg} / \mathrm{l})$. There was no significant difference $(P>0.05)$ in the mean monthly, seasonal and yearly values in both sampling stations (Fig. 3).

The mean monthly nitrate values varied significantly $(P<0.05)$. Topo sampling station recorded the highest values of 7.00 $\mathrm{mg} / \mathrm{l}$ and $9.00 \mathrm{mg} / \mathrm{l}$ in June and October of 2003 and 2004, respectively (Fig. 3). Variations in sampling stations and seasons were not significant $(P<0.05)$. Values of phosphate in the wet season, had significantly higher $(P<0.05)$ values compared to dry season, and highest value of $5.20 \mathrm{mg} / 1$ was observed at Akarakumo in June 2003 (Fig. 3). Free carbon dioxide lowest mean monthly value recorded was in May at both stations in the 2 years of study. The records for the creek ranged from $0.80-10.00 \mathrm{mg} / \mathrm{l},($ mean $=4.00 \pm 2.07 \mathrm{mg} / \mathrm{l})$. Significant difference $(P<0.05)$ was observed in months, seasons and years with both stations, recording maximum values in the 2 years of study (Fig. 3).

Total hardness $\left(\mathrm{CaCO}_{3}\right)$ mean concentration for the creek was $1244.15 \pm 2044.61$ $\mathrm{mg} / \mathrm{l}$ during the period of study. Significant difference $(P<0.05)$ was recorded for seasons and months (Fig. 4). The highest values $($ mean $=4757.00 \pm 5192.17 \mathrm{mg} / \mathrm{l})$ were obtained in March at Topo. Total hardness $\left(\mathrm{MgCO}_{3}\right)$ mean value for the creek was $612.96 \pm 1497.41 \mathrm{mg} / \mathrm{l}$ (range = 42.00-9899.00 mg/l). Significant variation $(P<0.05)$ in months and seasons was discernable (Fig. 4), with the highest value in June 2004 at Topo station.

Values of conductivity varied seasonally $(P<0.05)$, with wet season higher in both locations and years of study (Fig. 4). The mean composite figure for the creek was $2,154.59 \pm 3,232.82 \mu \mathrm{s} / \mathrm{cm} ;$ range $=$ 


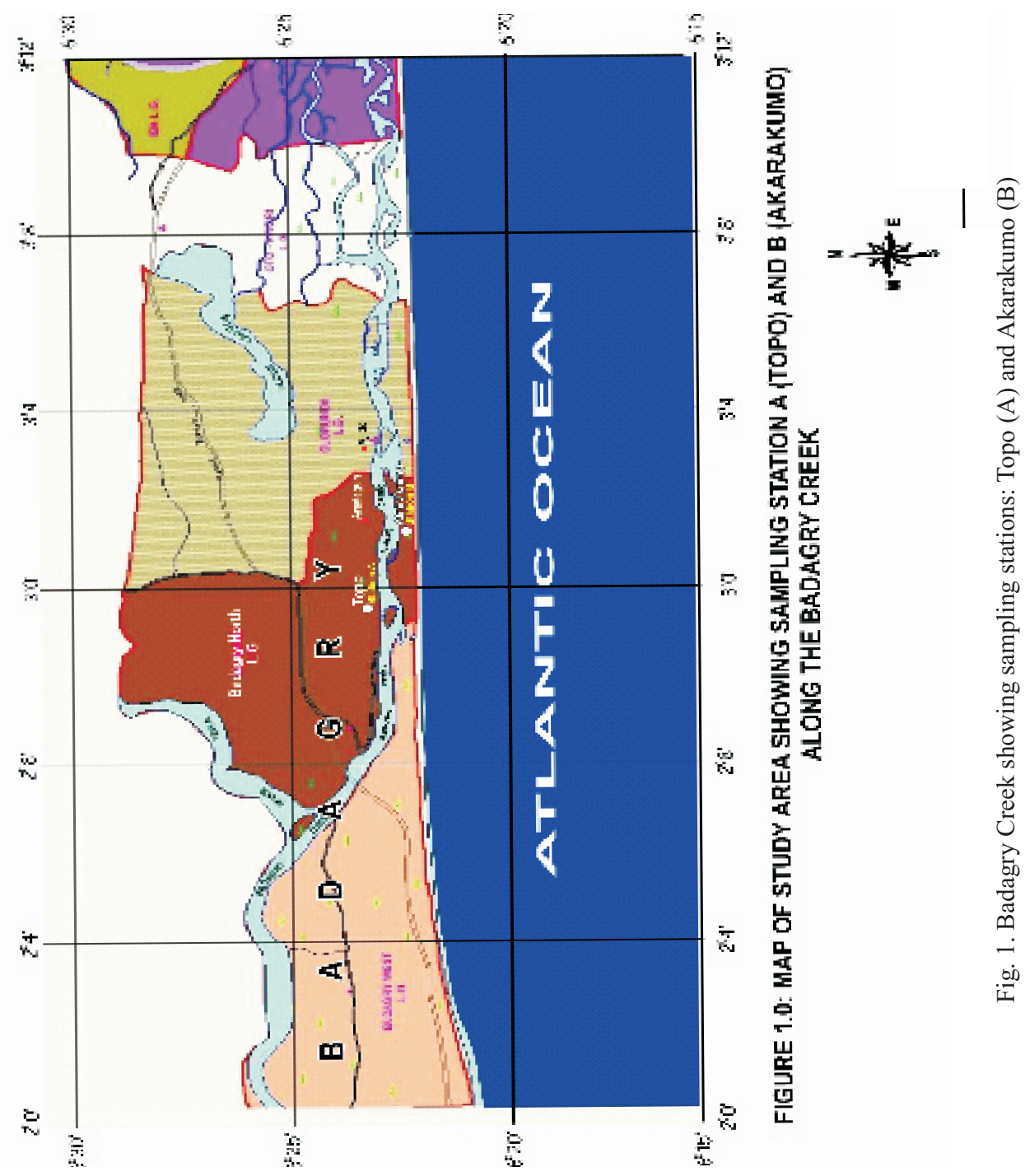




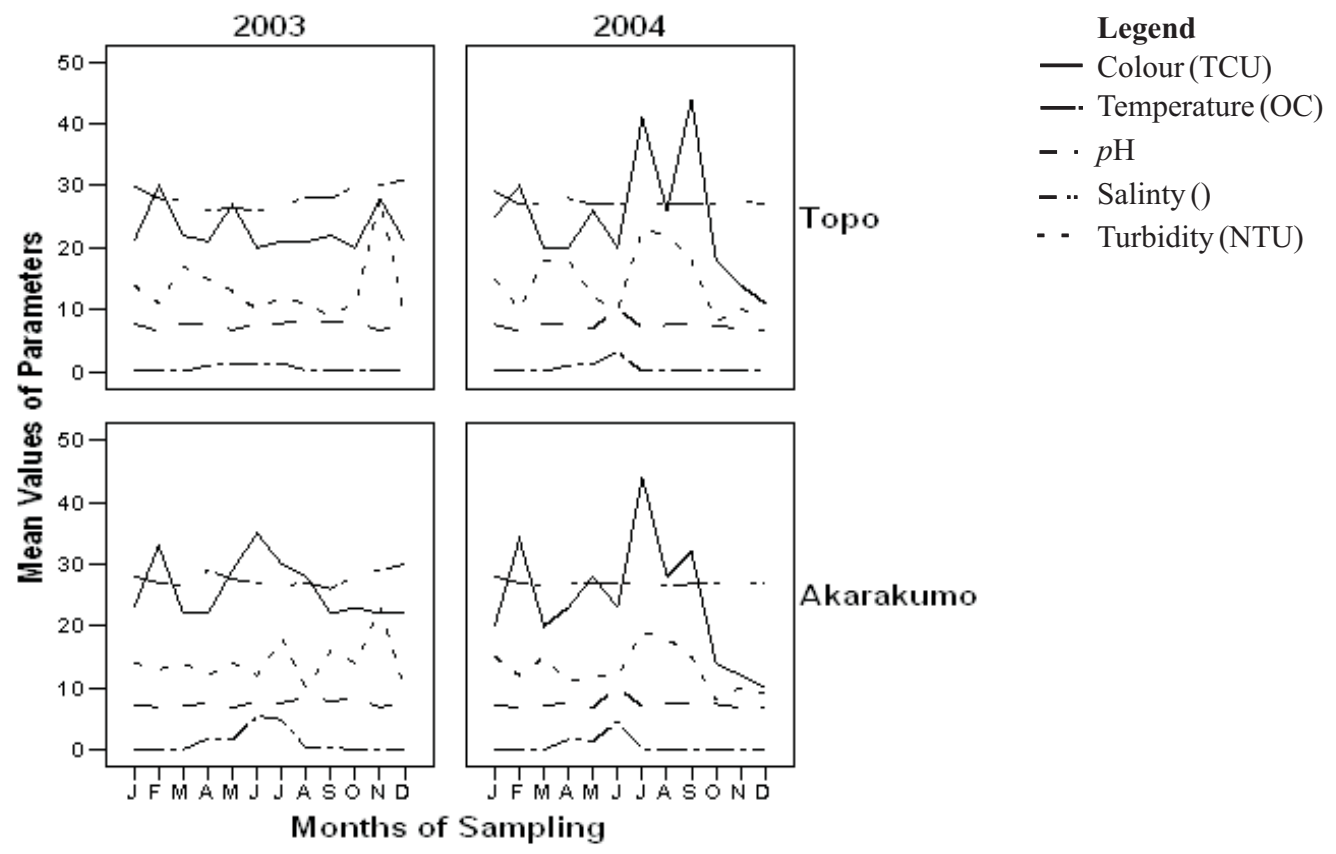

Fig. 2. Mean monthly dissolved colour, temperature, $p \mathrm{H}$, salinity and turbidity at the sampling stations in Badagry Creek, 2003-2004.

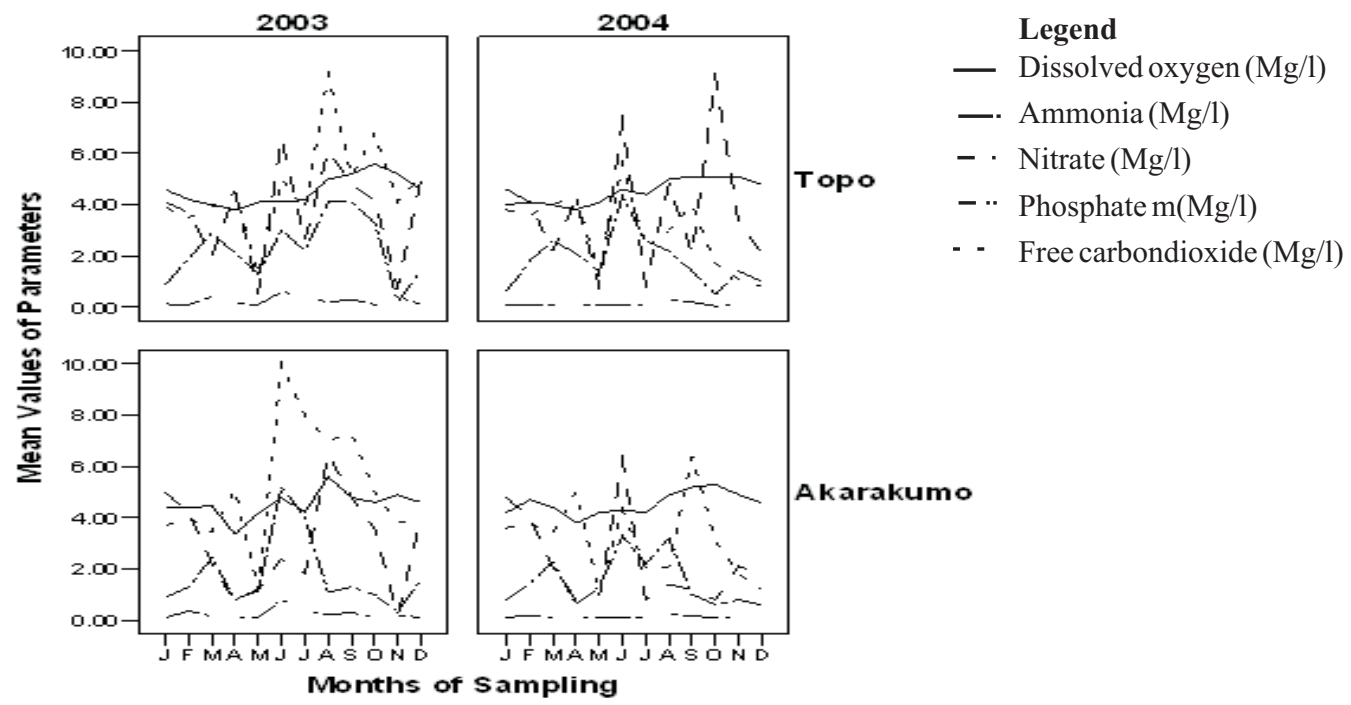

Fig. 3. Mean monthly dissolved oxygen, ammonia, nitrate, phosphate and free carbon dioxide at the sampling stations in Badagry Creek, 2003-2004. 


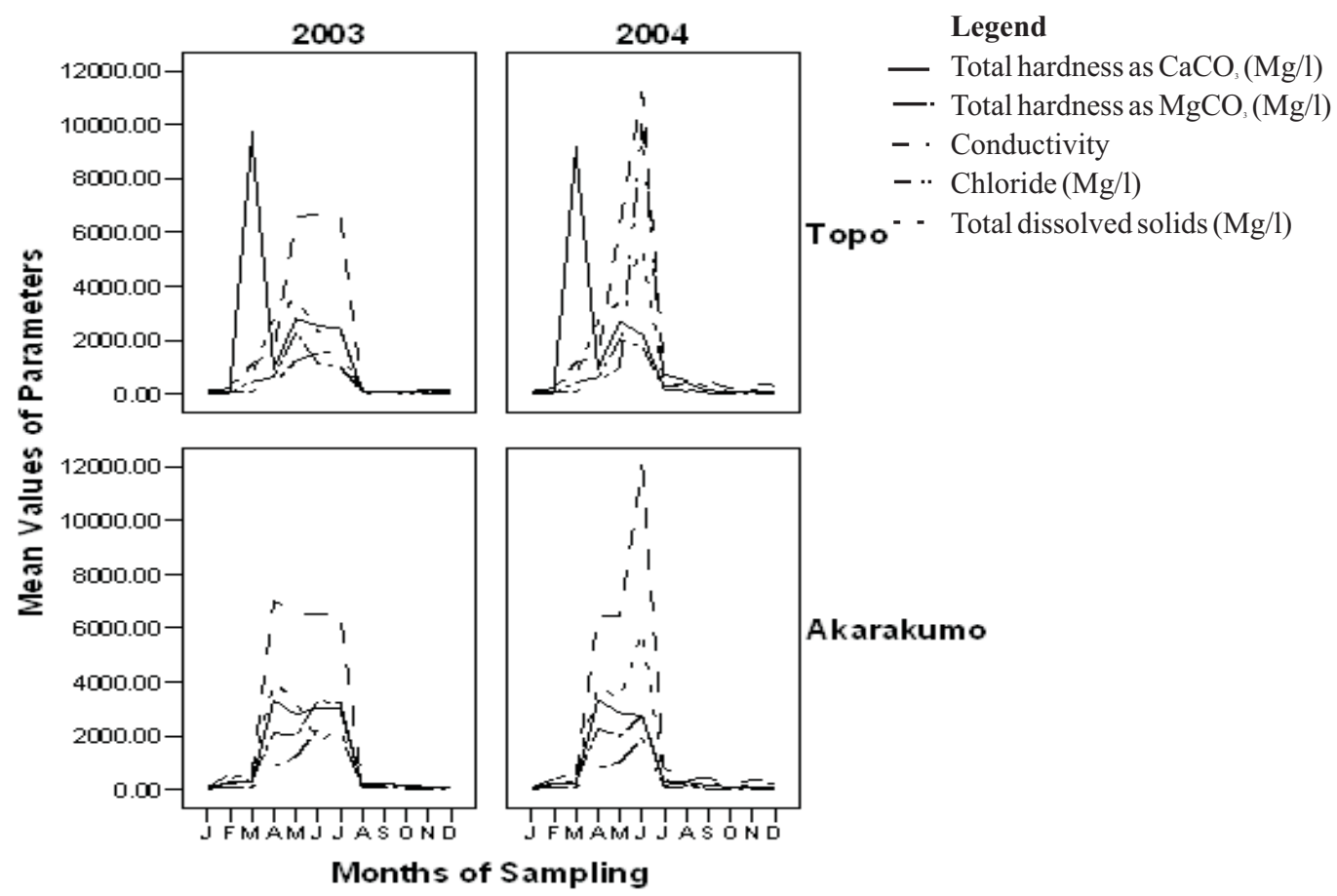

Fig. 4. Mean monthly total hardness $\left(\mathrm{CaCO}_{3}\right)$, total hardness as $\left(\mathrm{MgCO}_{3}\right)$, conductivity, chloride, and total dissolved solids at the sampling stations in Badagry Creek, 2003-2004.

$80.10-12,000.00 \mu \mathrm{s} / \mathrm{cm}$, the maximum value was obtained in June (both years). Variation in values from locations was not significant $(P>0.05)$. Significant variation $(P<0.05)$ was observed monthly and seasonally in the values of chloride (Fig. 4) composite mean concentration was $648.65 \pm 956.67 \mathrm{mg} / \mathrm{l}$ (range $=10.10-3306.00 \mathrm{mg} / \mathrm{l})$. The highest values of $3306.00 \mathrm{mg} / \mathrm{l}$ and $2750.00 \mathrm{mg} / \mathrm{l}$ were observed in June 2003 and 2004, respectively, while variation in sampling stations was not significant $(P>0.05)$. Total dissolved solids in creek varied significantly $(P<0.05)$ seasonally and monthly, with the highest value of $5,882.00 \mathrm{mg} / \mathrm{l}$ in June at Akarakumo (Fig. 4).
Sulphate mean concentration for the creek ranged from 0.50 to $689.00 \mathrm{mg} / \mathrm{l}$ (mean $=$ $148.79 \pm 201.09 \mathrm{mg} / \mathrm{l})$. Mean monthly variation was significant $(P<0.05)$, with the highest values of $689.00 \mathrm{mg} / 1$ and 670.00 $\mathrm{mg} / \mathrm{l}$ in April at both sampling stations in 2003 and 2004, respectively (Fig. 5). The mean monthly values of acidity (mean $=$ $14.88 \pm 12.27$, range $=2.00-65.00)$ varied significantly $(P<0.05)$ and highest value was obtained in both sampling stations in November 2003 (Fig. 5).

Differences in the season, years and locations were not significant $(P>0.05)$. Biochemical oxygen demand (BOD) mean values recorded in the period of study are 


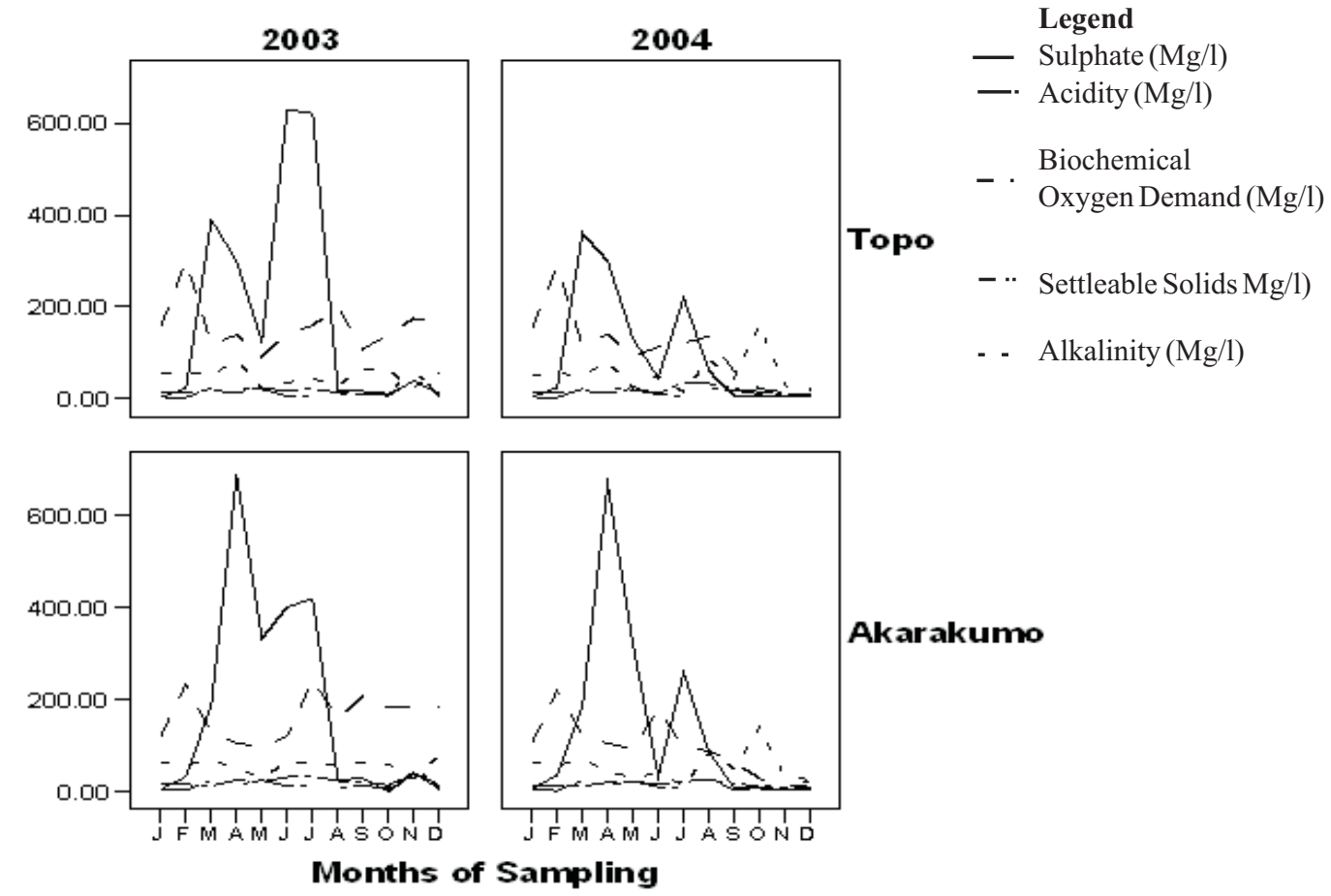

Fig. 5. Mean monthly sulphate, acidity, biochemical oxygen demand, settleable solids and alkalinity at the sampling stations in Badagry Creek, 2003-2004.

presented in Fig. 5. Significant difference $(P$ $<0.05$ ) was observed in months and years of study, with the highest value of $300.00 \mathrm{mg} / 1$ recorded at Topo in February 2003 and lowest value of $10.00 \mathrm{mg} / \mathrm{l}$ in December $2004 \mathrm{mg} / \mathrm{l}$. Fig. 5 shows mean monthly values for settleable solids in the years of study (mean $=$ $18.38 \pm 8.14 \mathrm{mg} / \mathrm{l}$, range $=8.00-42.00 \mathrm{mg} / \mathrm{l})$. Values for wet season was significantly different $(P<0.05)$ with the highest value obtained in November 2003 in both stations. Mean monthly alkalinity is presented in Fig. 5. Significant different $(P<0.05)$ in values was recorded in months and seasons with October $($ mean $=105.50 \pm 52.04 \mathrm{mg} / \mathrm{l})$ recording the highest values in both stations in 2003-2004.

\section{Discussion}

Colour values for the creek were higher in the wet season, a situation traceable to influx of suspended matter with rainfall which tends to interfere with light. The pattern of human activities in both locations were similar and there were no incursion in the creek before, and in between the two points of sampling that could have led to wide difference in value. Year to year variation in physical and chemical parameters is not a common feature of the tropics (Evans, 1982).

Surface temperature range of $26-31^{\circ} \mathrm{C}$ is comparable to other African water bodies reported in Mustapha (2008). Observed variations in temperature were due to 
measurement time. Temperature is known to change during a single day period, and, as a matter fact, Evans (1982) stated that constancy of temperature within one day is not a characteristic of the tropics.

The $p \mathrm{H}$ range of 6.6-10.2 was above the optimal range, recommended for prawns and fish production by Arrignon et al. (1994) and Boyd (1979). However, the mean value of $7.48 \pm 0.74$ recorded for the creek is within the optimum range reported for fish survival. Most natural water bodies are known to have a $p \mathrm{H}$ range of 5-10 (Tepe et al., 2005). Also, the higher values in wet season and lower values in the dry seasons reflect movement of salt water in or out of the creek. Karikari et al. (2007) reported similar finding in Korle lagoon, Ghana. Michael (1992) had reported diurnal variation in $p \mathrm{H}$ for surface water. Values in the study were consistent with the observations for Lagos lagoon by Olaniyan (1968) and Vanden Bosseche \& Bernacesek (1990).

The salinity profile for Badagry Creek showed oscillation between a purely freshwater and brackish ecosystem. High salt content occurred in the creek during the rainy season and high tide, a situation traceable to the incursion of sea water from the ocean. Similar observation had been reported by Ezenwa (1981). Since the Badagry Creek is of strong salt and freshwater mixing, it can be classified as a middle estuary, as described by Fairbridge (1980).

Turbidity variation in the creek showed a pattern which is not governed by season. This is at variance to observation by Udolisa (1984) since the two seasons had experienced both peak and ebb periods almost in the same period. Turbidity, caused by suspended soil particles, seldom have direct effects on fish though may adversely affect fish populations according to Boyd (1979).

The mean dissolved oxygen value recorded for the creek was within the optimum range (3-12 mg/l), which Boyd (1979) suggested will support growth of fish in a reservoir, but slow growth may occur. Dissolved oxygen concentration of the creek decreased with increasing salinity, and this was similar to observation by Boyd (1979). Michael (1992), nevertheless, averred that warm water species survive for long periods at dissolved oxygen as low as 2 or $3 \mathrm{mg} / 1$.

Wootton (1992) noted that low oxygen concentration in water were often caused by the presence of decaying organic matter, which generate toxic gases such as hydrogen sulphide and methane. During sampling period Badagry Creek was found to be heavily infested with water hyacinth, Eirchhornia crassipes, and partly with water lettuce and, Pistia sp. The weeds were gradually dislodged by the saline water of the creek, where they withered away, the result of which could lead to depletion of the oxygen concentration of the water.

The lowest oxygen concentration from all the sampling stations was recorded in April. This phenomenon is explained by the trend reported by Ezenwa (1981) for Badagry lagoon, and the changes in oxygen concentration are attributed to dynamics of respiration and photosynthesis. Kusemiju et al. (1993) recorded a range of $5.6-6.5 \mathrm{mg} / 1$ in the rainy season and $3.90-4.2 \mathrm{mg} / \mathrm{l}$ in the dry season for Opobo channel. Observation from this study, however, differs as period of rainy season had much lower value compared to that of dry season.

The recorded concentration of ammonia in Badagry Creek was relatively not dispersed 
at mean $=0.18 \pm 0.15 \mathrm{mg} / \mathrm{l}$ from a value range of $0.05-0.80 \mathrm{mg} / \mathrm{l}$. The monthly level of ammonia concentration, and, in term of sample location, did not show significant variation $(P>0.05)$ while the level was significant annually $(P=0.002)$. Sources of ammonia include atmospheric deposition, the breakdown of vegetation and animal wastes, applied artificial fertilizers and urban runoff, and these are significant, even in industrial areas (International Programme on Chemical Safety (ICPS) 1986). The source of ammonia in 2003 may have been due to runoff while values obtained for other year and months may be due to combination of atmospheric deposition, the breakdown of vegetation and animal wastes.

The mean composite value of $3.19 \pm 2.07$ $\mathrm{mg} / \mathrm{l}$ for nitrate was below the $10.00 \mathrm{mg} / 1$ level, which Michael (1992) indicated that, above the level, the nitrate is harmless but the water may have toxic substance and pollutant from industrial or agricultural sources. The absence of clearly defined difference in season's concentration of nitrate shows that the source may have been from aquifer recharge zone of the creek, and other sources although runoff from the rain may have heightened the concentration.

There was significant difference in values of phosphate recorded for the months $(P=$ $0.0001)$ while the values obtained for the sampling stations and years of study were not significant $(P>0.05)$. Izonfuo \& Bariweni (2001) reported similar observation for the level of phosphates in Epie creek, where lower value was obtained in the dry season than in the wet season. This means that runoff water contributes a significant proportion of the phosphate in Badagry Creek. The levels of phosphates were found to be higher than the range of $0.01-0.03 \mathrm{mg} / 1$ for phosphorus normally found in uncontaminated streams as defined by United States Department of Agricultural Soil Conservation Service (USDASCS) (1975). Phosphates and nitrates are important ingredients to plant blooms and the eutrophication of lakes and streams. Badagry Creek was found to be heavily infested with water hyacinth, Eirchhornia crassipes, and partly with water lettuce and Pistia sp. in November to February.

The concentration of free carbon dioxide in Badagry Creek showed wide fluctuation across sampling stations, months and years of study, but never rose above the $10.00 \mathrm{mg} / \mathrm{l}$. The variations were significant for the years of study $(P<0.05)$. Michael $(1992)$ asserted that free carbon dioxide concentrations in surface water are usually less than this value and vary diurnally. Nevertheless, free carbon dioxide concentration less than $10.00 \mathrm{mg} / \mathrm{l}$ are usually tolerated by fish if dissolved oxygen concentrations are near saturation (Michael, 1992). However, value above $10.00 \mathrm{mg} / \mathrm{l}$ are known to cause mineral deposits within kidney tubules, collecting ducts and ureters according to Michael (1992) although, in the view of Landolt (1975), the condition rarely results in high mortality in fish unless other environmental conditions are marginal.

Total hardness mean value of $1244.15 \pm$ $2044.61 \mathrm{mg} / 1$ recorded ranged from $90.10-9500.00 \mathrm{mg} / \mathrm{l}$. The highest value was recorded in March of both years at Topo. Outside this value the concentrations for other months were close. The highest values, recorded within the period of high salinity and low concentrations, were recorded during the lowest salinity regime. The observation followed the pattern described 
by Michael (1992) for freshwater and salt water total hardness as $\mathrm{CaCO}_{3}$. The concentration of total hardness pattern noticed in this study suggests that the values of total hardness in the creek were subjected to influence of season. High values of total hardness in Topo sampling station in the 2 years of study show that hardness was from the geology of the watershed in this particular area of the creek. Piper et al. (1982) stated that adequate hardness is desirable because environmental calcium deficiencies in water may cause poor survival, decreased growth, or poor disease resistance in fry. Increased environmental calcium concentrations decrease the toxicity of ammonia (Tomasso et al., 1980).

The concentration of total hardness $\left(\mathrm{MgCO}_{3}\right)$ observed in the creek points to the direction that total hardness is also related to the concentration of salinity. Michael (1992) indicated that total hardness for salt water environment is higher than the freshwater environment. The dynamic nature of the creek between freshwater and brackish biomes in relation to total hardness as $\left(\mathrm{MgCO}_{s}\right)$ was reflected in this study.

Higher values of conductivity were recorded in both sampling stations for year 2004 in May and June compared to the value for the previous year. Therefore, the months of May and June in 2004 had more foreign elements or pollutants within the period compared to 2003 since conductivity level is related to the total dissolved solid in a given water system. The conductivity values of most freshwaters range from 10 to 1,000 $\mu \mathrm{S} / \mathrm{cm}$. The average value of conductivity of the creek in the period where the condition of freshwater prevailed showed that the values were higher than maximum value of 1,000 $\mu \mathrm{S} / \mathrm{cm}$. This suggests a different optimum value for brackish water condition.

The period of high concentration of chloride recorded in the creek coincided with the period when the salinity level was quite high and, thus, monthly concentration had significant difference $(P<0.05)$. This observation is consistent with that of Michael (1992) who affirmed that chloride is usually the major anion in water of high salinity, and further noted the importance in the culture of brackish water or marine species. Furthermore, Lewis \& Morris (1986) stated that concentrations of chloride greater than $20 \mathrm{mg} / \mathrm{l}$ are desirable in intensive freshwater fish culture systems.

The composite mean concentration of total dissolved solids in the Badagry Creek was $1151.65 \pm 1565.83 \mathrm{mg} / \mathrm{l}$ and a range of $40.00-5882.00 \mathrm{mg} / \mathrm{l}$. The difference in the values recorded for the months were significant $(P=0.0001)$ but not for the sampling locations. The values recorded in monthly rainfall were considerably higher with a range of 500-5882.00 mg/l compared to $40-500.00 \mathrm{mg} / 1$ recorded in the dry season. It is safe to say that TDS of the creek is dependent on season and influenced by organic sources such as leaves, silt, plankton, and industrial waste and sewage.

The sulphate concentration was below 200-400mg/l recommended for drinking water and aquatic life by FEPA (1991). The concentration of sulphate observed showed wide seasonal variation. Monthly variation was significant $(P<0.05)$ for the sulphate and is accounted for by the values in the rainy season, thus, influence of runoff is of importance in the level of sulphate concentration in the creek. A positive 
correlation $\left(R^{2}=0.084\right)$, though weak, was observed in this study between the concentration of sulphate and settleable solid. This observation is similar to that obtained for Epie Creek by Izonfuo \& Bariweni (2001).

The highest concentration of acidity recorded was in November 2003 for the two sampling stations. There were wide variation in the values of acidity although they were not statistically significant $(P>0.05)$. This contrasts with the lowest value of $p \mathrm{H}$ recorded in the same month. Acidity and $p \mathrm{H}$ have an inverse relationship. European Inland Fisheries Advisory Commision (EIFAC, 1969) was of the view that acidification of highly alkaline water can increase the free carbon dioxide concentration, resulting in $\mathrm{CO}_{2}$ toxicity rather than $p \mathrm{H}$ imbalance. Fromm (1980) indicated that $a p \mathrm{H}$ of 6.5 , or higher, is needed for normal reproduction in fishes, and deducing from this a lower level of acidity concentration would support growth of fish.

Boyd (1979) asserted that standard biochemical oxygen demand is of little use in fish culture, where the momentary rate of consumption of DO by the microscopic organisms in the water is of more interest. The mean value for the creek was $130.27 \pm 67.59$ $\mathrm{mg} / \mathrm{l}$ with a range of $10.00-300.00 \mathrm{mg} / \mathrm{l}$, which is relatively high and indicative of the volume of domestic pollution along the creek. The bank and a few metres in to the creek were used by the community for washing, meat processing, especially pork, to mention but a few. In fact, virtually all human activity, implicated for causing pollution or loading of an aquatic system by Odiete (1999), takes place along the creek except for industrial activity.
The settleable solid mean value of $18.38 \pm$ $8.14 \mathrm{mg} / \mathrm{l}$ and a range of $8.00-42.00 \mathrm{mg} / \mathrm{l}$ were recorded in this study for the creek. There is no legal standard for TSS, but values below $30.0 \mathrm{mg} / 1$ are generally considered low, and values above $100 \mathrm{mg} / \mathrm{l}$ are considered high. However, the value may be indicative of the physical, geological and biological processes at the position and time of sampling according to Morris (1985). The settleable solid showed wide variation in November such that the values for 2003 in both sampling stations were higher than those recorded in year 2004. The values recorded for other months were close in the years and at sampling locations. TSS quantifies solids by weight is heavily influenced by stream flow and land disturbing activities. A good measure of the upstream land use conditions is how much TSS rises after a heavy rainfall. In this study higher values of settleable solid were recorded in the periods of rainfall than in the dry season.

The alkalinity mean value of $54.08 \pm 27.76$ $\mathrm{mg} / \mathrm{l}$ was recorded in the creek. A 50-mg/l had been reported for natural waters of Hatay region in Pakistan by Tepe et al. (2005). The value ranged from $12.10 \mathrm{mg} / \mathrm{l}$ to $160.00 \mathrm{mg} / \mathrm{l}$ recorded in October 2003. The high values above $20 \mathrm{mg} / \mathrm{l}$ recorded suggest that the creek was buffered all through and accounts for the almost neutral $p \mathrm{H}$ (mean $=7.48 \pm 0.74)$ value. Boyd (1979) stated that water with high alkalinity tends to be more buffered than that of low alkalinity.

\section{Conclusion}

The physical and chemical parameters of the creek as indicated in this study represent optimum conditions that would support 
many organisms. Also, there is need to conserve the estuarine conditions of the creek in view of its uniqueness and the particular importance of estuaries globally in the life cycle of many aquatic species of tremendous importance to both local and international fisheries with the fact that the creek runs through two different countries.

\section{References}

Abegunde M. A. A. (2002). Aspect of the Physical Environment of Lagos. In History and People of Lagos state. (A. Adefuye, B. Agiri and J. Osuntokun, eds), pp. 6-15. Lantern Publications limited.

Ameka G. K., Ameka G.k., de Graft-Johnson K. A. A. and Adomako J. K. (2007). Water Quality at the Habitat of the Podostemaceae in Ghana. West Afr. J. appl.Ecol.11:54-62.

American public Health Association, American Water Works Association, and Water Pollution Control Federation (APHA, AWWA, and WPCF) (1985) Standard methods for the examination of water and waste water, 16th edn. American Public Health Association, Washington DC. 1268 pp.

Arrignon J. C. V., Huner J. V., Laurent P. J., Griessinger J. M., Lacroix D., Gondouin P. and Autrand M. (1994). Warm water crustaceans. The Macmillan Press Ltd, Technical Centre for Agriculture and Rural Cooperation (CTA).

Boyd C. E. (1979). Water Quality in Warm Water Fish Ponds. Auburn University Publications, Alabama Agric. Expt. Stations. 359 pp.

European Inland Fisheries Advisory Commision (EIFAC) (1969). Water quality criteria for European freshwater fish - Extreme $p \mathrm{H}$ values and inland fisheries. Wat. Res. 3: 593-611.

Evans J. (1982). Plantation Forestry in the Tropics. Oxford University Press, New York. p. 472.

Ezenwa B. I. O. (1981). A Study of the Reproductive Biology of the Catfish, C. nigrodigitatus (Lacepede), in Nigeria. (PhD Thesis.) University of Lagos, Nigeria. 178 pp.

Fairbridge R. W. (1980). The estuary: its definition and geodynamic cycle. In Chemistry and Biogeochemistry of Estuaries. (E. Olausson and I.
Cato, eds), pp. 1-35. J. Wiley and Sons, Chichester. Federal Environmental Protection Agency (FEPA) (1991). National Interim Guidelines and Standards for Environmental Pollution in Nigeria. pp. 54-58.

Fromm P. O (1980). A review of some physiological and toxicological responses of freshwater fish to acid stress. Envir. Biol. Fish. 5: 79-93.

International Programme on Chemical Safety (ICPS) (1986). Ammonia. Envir. Hlth Crit. 54: 250.

Izonfuo L.W.A. and Bariweni A. P. (2001). The Effect of Urban Runoff Water and Human Activities on some Physico-Chemical Parameters of the Epie Creek in the Niger Delta. J. appl. Sci. envir. Mgmt 5(1): 47-55.

Karikari A. Y. Asante K. A. and Biney C. A. (2007). Water Quality Characteristics at the Estuary of Korle Lagoon in Ghana. West Afr. J. appl. Ecol. 11.

Kusemiju K, Nwankwo D. I. and Bamisaye R. B. (1993). The Hydrology and Fishes of Opobo Channel, River State. Nig. J. Sci. Res. Dev. 1 (1): 74-79.

Landolt M. L. (1975). Visceral granuloma and nephrocalcinosis of trout. In The pathology of fishes (W. E. Ribelin and G. Migaki, eds), pp. 793-799. The University of Wisconsin Press, Madison,

Lewis W. M. and Morris D. P. (1986). Toxicity of nitrite to fish: A review. Trans. Am. Fish. Soc. 115: 183-195.

Micheal K. S. (1992). Fish Medicine. W.B Saunders Company. $881 \mathrm{pp}$.

Morris A. W. (1985). Estuarine Chemistry and General Survey Strategy. In Practical Estuarine Chemistry. (P. C. Head, ed.), pp. 1-60. Cambridge University Press.

Mustapha M. K. (2008). Assessment of the Water Quality of Oyun Reservoir, Offa, Nigeria, Using Selected Physico-Chemical Parameters. Turk. J. Fish. aquat. Sci. 8: 309-319.

Odiete W. O. (1999). Environmental Physiology of Animals and Pollution. Pub. Diversified Resources Ltd. p. 215.

Olaniyan C. I. O (1968). An Introduction to West African Animal Ecology. Heinemann Educational Books Ltd. Ibadan. 167 pp.

Peter C. and Michael E. H. (2005). Marine Biology, 5th edn. McGraw-Hill. 452 pp.

Piper R. G., McElwain J. B., Orne L. E., McCraren J. P., Fowler L. G. and Leonard J. R. (1982). Fish 
Akintola et al.: Some physicochemical charateristics of Badagry creek, Nigeria

Hatchery Management. United States Department of Interior. Fish and Wildlife Service, Washington DC.

Statistical Package for Social Science (SPSS) (2001). SPSS for Window. Release 11 Standard Version. Copyright SPSS Incorporation, 1989-2001.

Tepe Y., Turkmen A., Mutlu E. and Ates A. (2005). Some physico-chemical characteristics of Yarsell Lake, Turkey. Turk. J. Fish. aquat. Sci. 5: 35-42.

Tomasso J. R., Goudie C. A., Simco B. A. and Davis K. B. (1980). Effects of environmental $p \mathrm{H}$ and calcium on ammonia toxicity in channel catfish. Trans. Am. Fish. Soc. 109: 229-234.

Udolisa R. E. K. (1984). A Techno-Economic Consideration of Beach Seine Fishery of Ibeshe Sea Village, Badagry Lagos State. (MSc Thesis.) University of Ibadan, Ibadan. 83 pp.
United States Department of Agricultural Soil Conservation Service (USDASCS) (1975). Agricultural waste management. Field Manual, U.S. Printing Office. 1(1).

Vander Bossche J. P and Bernacesek G. M. (1990). Source Book for Fishery Resources of Africa. CIFA Tech. Pap. No. 181. FAO, Rome. 240 pp.

Wootton R. J. (1992): Fish ecology, Blackie, New York. 212 pp.

Zalids G., Stamatiadis S., Takavakoglou V., Eskridge K. and Misopolinos N. (2002). Impacts of Agricultural Practices on soil and Water Quality in the Mediterranean Region and Proposed Assessment Methodology. Agric. Ecosyst. Envir. 88: 137-146. 